\title{
BETWEEN URBAN AND RURAL: SUSTAINABILITY OF SMALL TOWNS IN THE CZECH REPUBLIC
}

\author{
Antonín Vaishar, Jana Zapletalová, Eva Nováková1
}

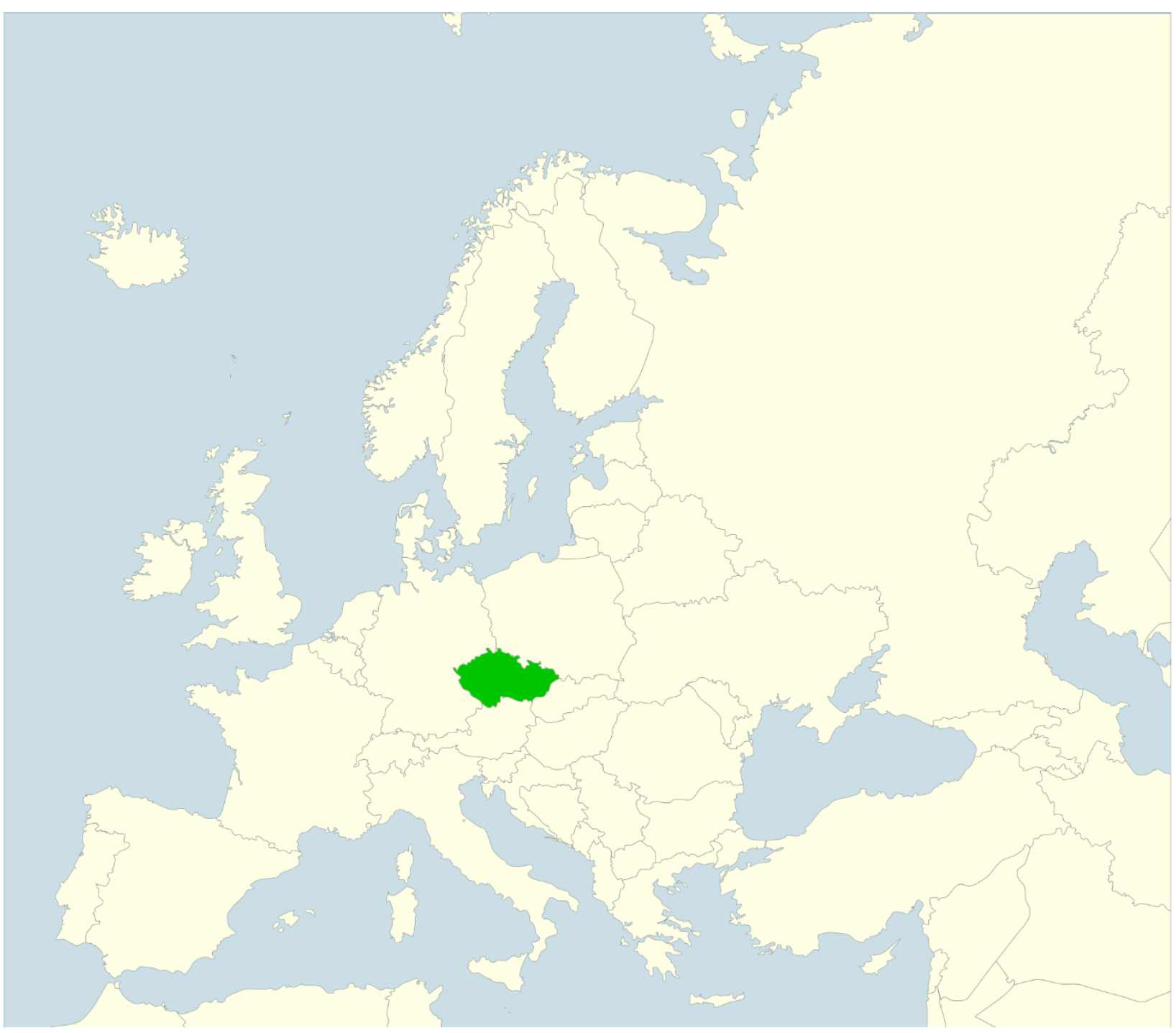

${ }^{1}$ Doc. RNDr. Antonín Vaishar, CSc., RNDr. Jana Zapletalová, CSc., Mgr. Eva Nováková, Institute of Geonics, Czech Academy of Sciences Ostrava, v.v.i., Department of Environmental Geography, 60200 Brno, Drobného 28; e-mails: vaishar@geonika.cz; zapletalova@geonika.cz; novakova@geonika.cz 


\begin{abstract}
The paper analyses the position of small towns in the Czech settlement system. It deals with the definition of small towns, their geographical positions, demographic characteristics and functions in the national settlement system. A typology of small towns aimed at individual pillars of their sustainability is one of the results of the paper. The article discusses the position of small towns as part of the urban world and their position as a part of the countryside. It concludes that small towns are functionally important as rural centres. However, differences between urban and rural seem to be less important than differences among individual types of the Czech countryside (suburban, intermediate, inner periphery, borderland).
\end{abstract}

Key words: small towns, sustainability, Czechia

Souhrn: Článek analyzuje postavení malých měst $v$ českém systému osídlení. Zabývá se definicí malých měst, jejich geografickou polohou, demografickými charakteristikami a funkcemi $v$ systému osídlení. Jedním z výsledků je typologie malých měst. Př́spěvek diskutuje roli malých měst jako součástí městského světa a jako součásti venkova z hlediska jednotlivých piliřru jejich udržitelnosti. Dochází k závěru, že funkční význam malých měst spočivá $v$ jejich roli středisek venkova. Nicméně rozdíly mezi městským a venkovským se zdají být méně podstatné než rozdíly mezi jednotlivými typy českého venkova (suburbáním, mezilehlým, vnitřní periferií, pohraničím).

Klíčová slova: malá města, udržitelnost, Česko

\title{
1. Introduction
}

Small towns in rural areas form a bridge between social community capital and ecological cultural heritage, on the one hand and the new growth and creativity of the cities, on the other (Vaz et al., 2013). The Czech Strategy of Regional Development ${ }^{2}$ mentions the dense network of small and medium-sized towns as one of the strengths of the Czech regional development. Small towns enable to stabilise the Czech countryside in general. They offer jobs, services, social contacts, and transport connections to surrounding villages (Vaishar and Zapletalová, 2009). There is a very limited number of areas which are not sufficiently covered by small towns representing a rea periphery with all the consequences like out-migration, aging, unemployment, low educational structure etc. However, the majority of the countryside including inner and borderland peripheries with small urban centres develops relatively successfully.

Small towns can be investigated basically from two viewpoints: urban and rural ones. Seen from a metropolitan perspective, small towns form an insignificant part of the settlement system with very low innovative potential. In the post-productive era they serve as places where the manufacturing industry (relocated from big and medium-sized cities) could be partly saved. Earlier small towns served also as transmissions between big cities and the countryside being rather a part of the countryside than a part of the urban world.

On the other hand, small towns seen from the rural point of view represent development poles within the countryside. They are perceived as urban features. However, this approach is applied only shortly. It has been pre-conditioned by an understanding that countryside is different from agriculture - which is a rather recent approach. Spasić and Petrić (2006) relate the increasing interest in small towns to the growing recognition of the importance of exchanges between rural and urban households, enterprises and economies. Belova and Levchenkov (2012) speak about innovative centres in small towns as an incubator of rural development.

As it was indicated above, the role of small towns is differentiated in the Czech territory. There are differences in size, position regarding to the distance to larger regional centres, transport accessibility, historical development, and human capital. Also regional differences can be found

2 Strategie regionálního rozvoje ČR 2014-2020. Ministerstvo pro místní rozvoj ČR. 
between urban and rural parts of the country including differences between Bohemia and Moravia. Nevertheless, differences in the role of small towns in individual types of the Czech countryside seem to be substantial first of all.

It is not easy to define the small town. In central European countries there is no official definition of small towns except in Germany where "Kleinstädte" have between 5 and 20 thousand inhabitants and/or the lowest centrality function within the German settlement system ${ }^{3}$. For the purpose of this paper, the upper limit (in contrast with a medium-sized town) has been delimited consistently with Hampl and Marada (2015) at 15,000 inhabitants. The lower limit (to distinguish them from rural seats) uses to be more problematic. It is felt that the simple application of the population numbers cannot capture the reality because specific central or other functions of individual small towns can be decisive. Because some small towns administratively include some distanced parts of clearly rural character, we use the population number of the urban core for the definition which is a decisive difference to the German definition - where this distinction cannot be made.

The paper is aimed at a typology of Czech small towns (from 3 to 15 thousand people) from different viewpoints (geographical position, size, function and economy). Individual towns will be evaluated by size, regional position, accessibility and functions. The types obtained will be confronted with indicators of demographic, economic and social sustainability. The main research question is whether indicators of sustainability show some relation to individual types of small towns.

\section{Small towns in the European context}

Europe is characterized by a relatively dense network of small towns. Research concerning small towns can be divided in three groups: analyses dealing with individual small towns, studies investigating small towns within a selected region and works focused on small towns as a specific phenomenon. In Central Europe, small towns play a specific role in peripheral regions. That is why small towns are investigated especially in the mountain territory of the Alps (Perlik and Bätzing 1999, Pumain 1999, Keckstein 1999, Borsdorf and Paal 2000, Zsilincsar 2003 or Convertino 2006) but similarly also in the southern part of France (Laborie 1997, Édouard 2012) and in inland Spain (Rodriguez Gonzáles 1997) - it means in regions with a significant share of rural areas. The intermediate position of small towns between urban and rural, between local and global is frequently discussed. Courtney and Errington (2003) paid their attention to small towns as a general issue. Halonen et al. (2015) show how industry cycles impact on a resource-based small town in Eastern Finland. However, the nature of European small towns seems to be different from the American ones (see Wuthnow, 2013), let alone small towns in the developing world.

The transformation of small towns from centrally planned to market conditions is usually the main topic of small town research in post-communist countries. German colleagues (Niedermayer 2000, Steinführer and Kabisch 2005, but also the Polish geographer Cudny 2012) dealt additionally with the situation of East German small towns after the German reunification which was characterised by de-industrialization, population decrease, de-urbanization and infrastructural shrinkage. Polish geography pays its attention to small towns as centres of the rural hinterland (Sokolowski 1999, Heffner and Marszał 2005, Rydz 2006). Zuzańska-Żysko (2004) studies small towns in Silesia, whereas Kwiatek-Sołtys (2004) focuses on Lesser Poland. A relatively new book characterizing the contemporary development of Polish small towns was edited by Krzysztofik and Dymitrow (2015). Their work shows differences between degraded and revitalized small towns. A systematic research is provided also by the Institute of Regional Geography in Leipzig (Borsig et al. 2010, Burdack and Kriszan 2013). Monographs or papers are also published in other post-communist countries (Slavík 2002, Rebernik 2005, Cigale et al. 2006, Lampič and Špes 2007, Kusis and Abele 2008, Zamfir et al. 2009). Also some works of the authors of this paper need to be mentioned (e.g. Vaishar and Greer-Wootten 2006, Vaishar et al. 2008 or Vaishar et al. 2012). Horeczki (2014) mentions (based on the empiric results from the SouthDanubian region) that the local economic potential of small towns consists of local traditions, practices, special age-long agricultural activities, specialized knowledge or economic attitude

\footnotetext{
${ }^{3}$ Klein- und Mittelstädte in Deutschland - eine Bestandsaufnahme (2012). Stuttgart: Franz Steiner Verlag
} 
(small firm production possibilities, special horticultural activities). The small towns sector is investigated also in Russia (Gunko 2014). However, the population limit is defined higher there (between 20 and 50 thousands).

Considered as a decisive feature of small town development, population development is often in the focus of research. For Czechia, Zemanová (2012) elaborated census data from 1869 - 2001 and provided evidence for a general population decrease. However, the de-urbanization processes were significant only after 2000 in Czechia. Similarly, Repaská (2011) analysed the demographic development of small towns in the Nitra Region (Slovakia). She also stated population decrease - although two small towns recorded a positive migratory balance. As for southern Moravia, Vaishar, Št’astná and Stonawská (2015) show significant differences among small towns in this region. In the period of 2008 - 2012, small towns with lower population number (closer to a rural character) and small towns closer to the regional centre showed a positive population development. In contrast, small towns in peripheral positions and small towns, which lost some important industrial plants, lose residents. However, in general, more small towns gained population in southern Moravia. As Ježek and Kaňka (2011) stated, the most significant problems can be expected in the small towns, which are situated in peripheral locations, especially in so called internal peripheries on the boundaries between single regions, which have been facing outmigration since the 1980s.

Small towns form a specific phenomenon of the settlement system. They are no miniatures of larger cities. They offer an alternative of a lifestyle for a certain part of the population. The difference could be expressed for example by a simple fact that citizens do not need a car to move in their small towns. A person walking or moving by bike perceives the settlement, its atmosphere and other people in a different way than an inhabitant of a city that moves by car or by public transport. The people can feel more secure in small towns than in big cities. According to Hannemann (2002), a special form of social capital originated in small towns. The people know each other, often keep some aspects of rural way of life and are able to cooperate. Some of small towns survived shocks connected with the transformation of central planned economy to the market one. These shocks were connected with closing of important factories or finishing of mining activities. Besser (2013) suggests that small towns with higher social capital including linkages among different social groups are more resilient in these cases.

Small towns create the lowest level of centres. Sýkora and Mulíček (2009) show that the everyday life of people is situated in a relatively large number of micro-regions ${ }^{4}$ with small towns, playing often the role of their centres. In other words, they manifest the highest level of the countryside and - at the same time - the lowest level of the urban system. This attribute is the reason of the increasing attention paid to small towns in geography in the last years. On the other side small towns differ from rural settlements by existence of a basic level of urban functions including services.

At the present time, geographers meet the necessity to rethink Christaller's theory of central places as a consequence of the development of individual transport and increasing motility of people. Rural inhabitants can therefore satisfy their demands for jobs and services in more distanced but better equipped medium-sized towns and big cities or in hypermarkets and industrial zones by motorway crossroads. It is true especially in well accessible towns in lowlands or in peri-urban zones. In contrast, peripheral small towns in badly accessible micro-regions keep they role longer due to non-existence of any competitors in their vicinity (Vaishar and Zapletalová, 2009).

Because small towns are considered as a part of the countryside in our study, they vary in different parts of the world according to the natural and historical conditions for development of agriculture and other productive and non-productive branches. They differ by the population number, character of housing, central functions etc. We avoid the analysis of small towns in the U.S.A., Africa, China, India, Australia, Russia and other parts of the Earth.

\footnotetext{
${ }^{4}$ A micro-region in the Czech conditions can refer to (1) a functional region integrated by commuting, (2) a territory administrated by municipal offices with extended competences, (3) areas of voluntary associations of communes (when they have a character of region). Small towns play an important role in all these cases.
} 


\section{Methodology and typology}

In this paper, small towns are defined as municipalities with urban rights while the population number of its core does not exceed 15,000 persons and is higher than 3,000 people. We took into account that the research is partly based on statistical data. Therefore, a statistical definition is needed. The upper limit is caused by the fact that there is a gap in the interval $15-20$ thousand inhabitants. Only a few non-district centres can be found in this category. These district towns are of different nature due to their functions. The lower limit is a compromise. In Moravian lowlands with a big number of larger settlements, municipalities of 3 - 4 thousand of residents are of rural character as a rule. In Bohemia with a more dispersed settlement structure, municipalities with lower than 3,000 inhabitants manifest often important centres. We also presuppose that municipalities with more than 3,000 inhabitants which do not have the town status have not asked for its conferment and thus they most probably lack the subjective feeling of being urban.

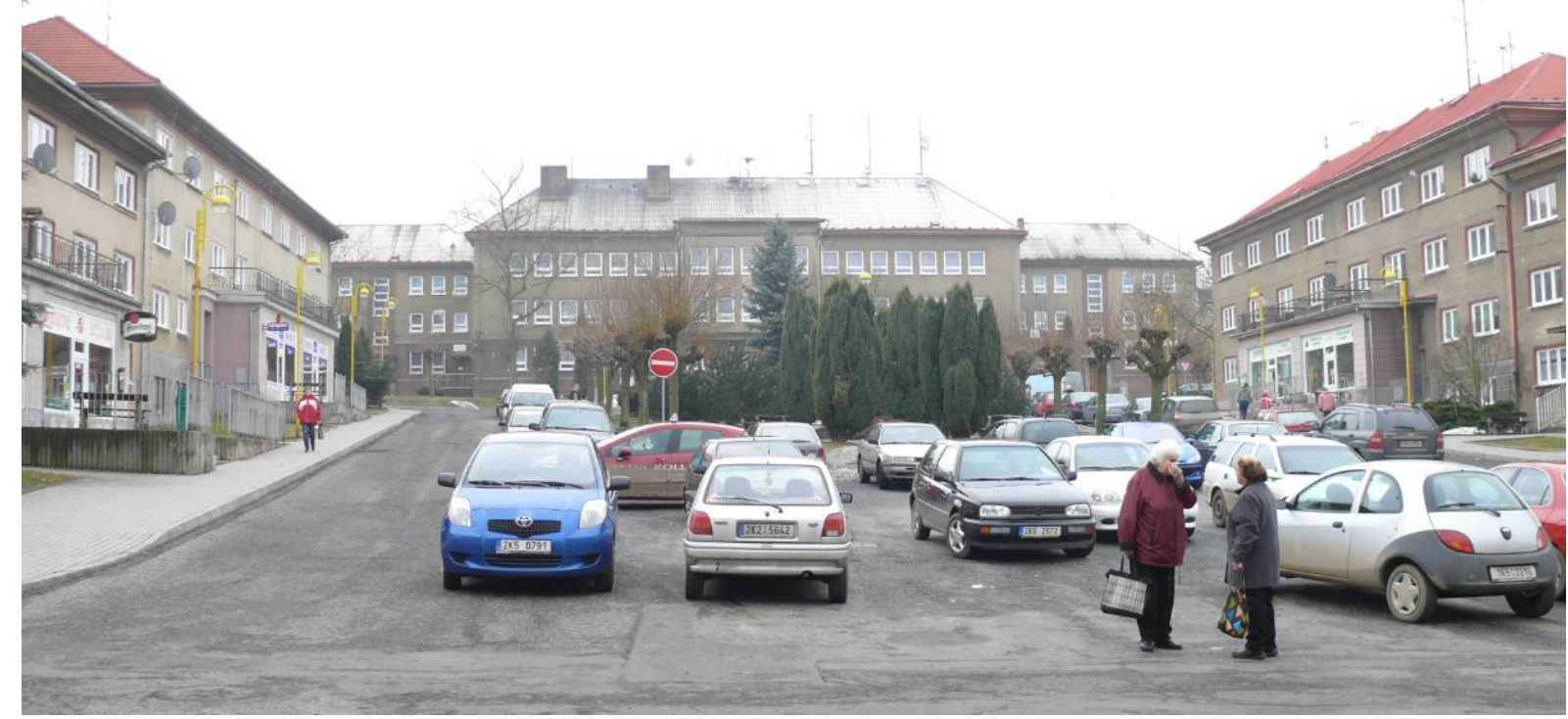

Fig 1. Chodov (Karlovarský Region): one of bigger small towns; originally known for its china ware, during the communist regime place of coal mining. Today, people mostly commute to Karlovy Vary or Sokolov. Photo: A. Vaishar

The first step of the analysis was to determine small towns from the whole set of more than 6,000 Czech municipalities. Altogether 283 small towns fall into this category on the Czech territory.

The whole set of towns has been divided also regionally in respect to the fact that the Czech national settlement system is formed by two relatively different settlement systems the centralized Bohemian and the transitional Moravian one with some particularities of the Silesian settlement type. The territory is divided into the following regions: the surroundings of Prague (districts Prague-East and Prague-West), Central Bohemia (remainder of the CentralBohemian region), Southern Bohemia (South-Bohemian region with the centre of České Budějovice including Pelhřimov district from the Vysočina region), North-western Bohemia (Plzeň and Karlovy Vary regions with the centre in PIzeň), North-eastern Bohemia (Ústí nad Labem and Liberec regions with the respective centres), Eastern Bohemian region (regions of Hradec Králové and Pardubice including district Havlíčkưv Brod from the Vysočina region), Southern Moravia (South-Moravian region, districts of Třebíč, Jihlava and Žd'ár nad Sázavou from the Vysočina region and Moravian small towns in South-Bohemian and Pardubice regions), Central Moravia (Zlín and Olomouc regions with the Moravian part of the Moravian-Silesian region with centres in Ostrava, Olomouc and Zlín) and Silesian region (Silesian part of the Moravian-Silesian region and district Jeseník from the Olomouc region). 


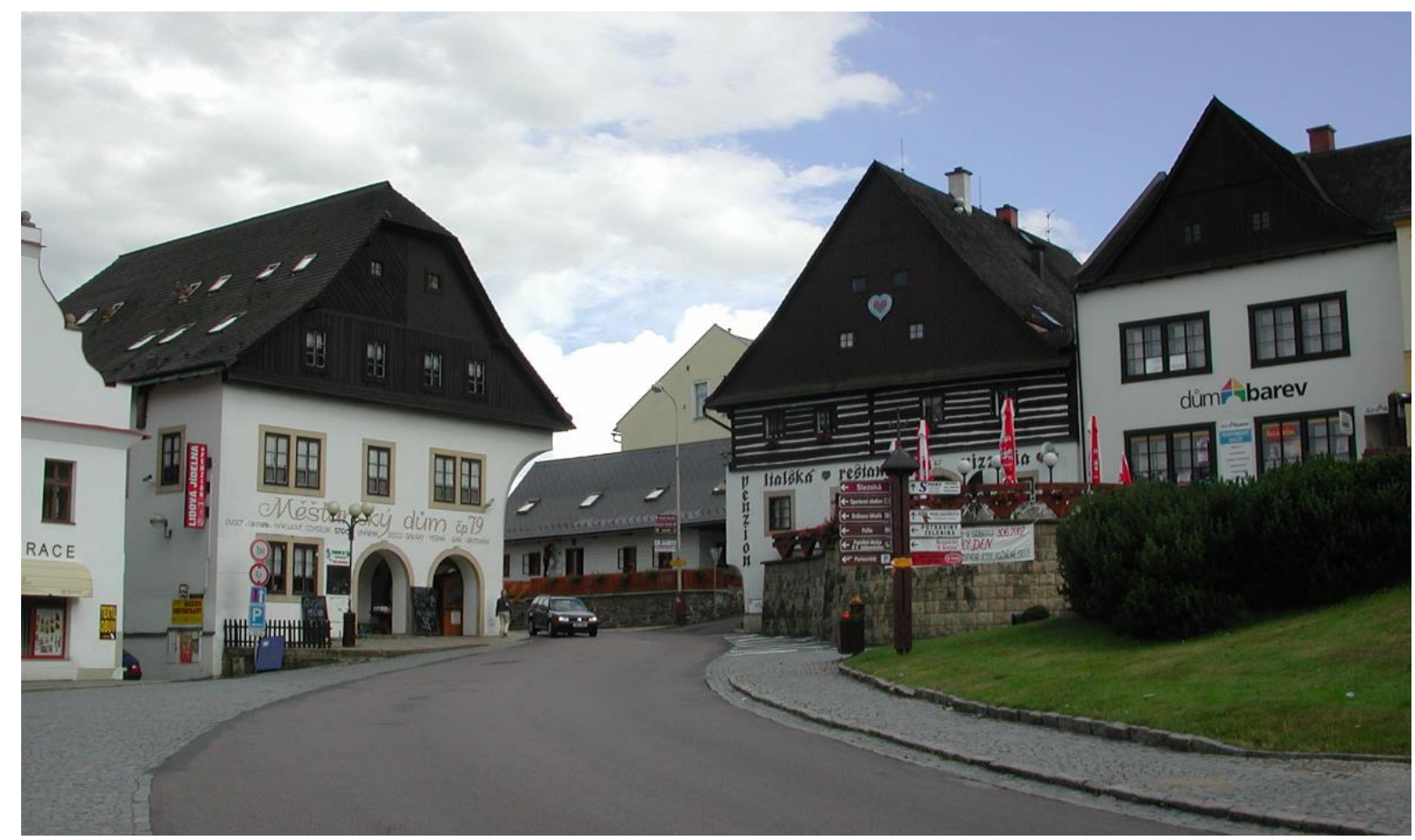

Fig 2. Jablonné nad Orlici - a typical town close to the Orlické hory (Eagle Mts.).

An analysis of their geographical position is the second step taking into account the accessibility of higher urban functions like universities, hospitals, theatres etc. It will be done by means of the time distance from the closest regional centre (centres of all administrative regions except for the smallest ones - Jihlava and Karlovy Vary ${ }^{5}$ ). The time distance is a combination of the geometric distance and realistic accessibility. It is derived from the Czech cartographic server mapy.cz and measured in minutes. We agree that the regional centres found by such a way are not equivalent. Prague is much stronger than Brno which again is stronger than the remaining smaller centres. On the other hand, some small towns gravitate partly to sub-centres like Opava, Jihlava, Karlovy Vary or Mladá Boleslav. However, knowing the Czech situation we are of the opinion that our classification strongly corresponds with the aim of the typology. It is also necessary to make clear that an access of the city centre by individual car was taken into account. In the case of Prague, the time to pass through the city is substantially longer than in the case of other regional centres.

Further an attempt to create a functional typology of small towns is made. Among others, the following aspects were taken into account: job offer and manufacturing function. In our opinion, these two indicators characterize in which branch of the economy the population of the respective small towns are more engaged in comparison with the whole set of small towns and whether it is their own activity or it is realized in some different job centre. Data from the Czech Ministry of Finance ${ }^{6}$ and the 2011 population census are used. The job offer is calculated as the number of employees in the town minus the number of economic active residents of the town plus the number of commuters for work. An estimation of jobs which are "available" for the people outside the town is the result which indicates the central importance of the town in the labour market. The resulting set of small towns was divided into five groups: very important job centres, important job centres, weak job centres, small towns ensuring jobs for their own inhabitants and small towns depending on neighbouring job centres.

\footnotetext{
${ }^{5}$ The reason lies not only in the size of the mentioned centres but also in their functions as they are, for example, the only regional towns without any public university. Contrary to our standpoint, Hampl and Marada (2015) exclude Jihlava but keep Karlovy Vary.

${ }^{6}$ The decree of the Ministry of Finance no. 281/2012 Col. from August 25, 2014 about the share of individual municipalities on specified percentage parts of the national gross return of value added and income taxes which contains numbers of employee in each municipality; the older data were used because of their time compatibility with the population census 2011 .
} 
The economic typology was made according to the share of employees in individual economic branches. The following branches were evaluated: primary sector (agriculture, forestry and fishery), industry including construction (Fig. 2), commercial services (mainly retail, transport, communications, and repair shops), tourism services (accommodation, gastronomy, Fig. 3) and social services (education, health care, social care, administration etc.). Of course, if we take into account absolute data almost all small towns in Czechia are industrial (including construction industry) with a very small number of exceptions mainly in vicinity of large centres. That is why the relative values of the indicator were used. The values express a prevalence of the most represented branch in relation to the whole set of small towns.

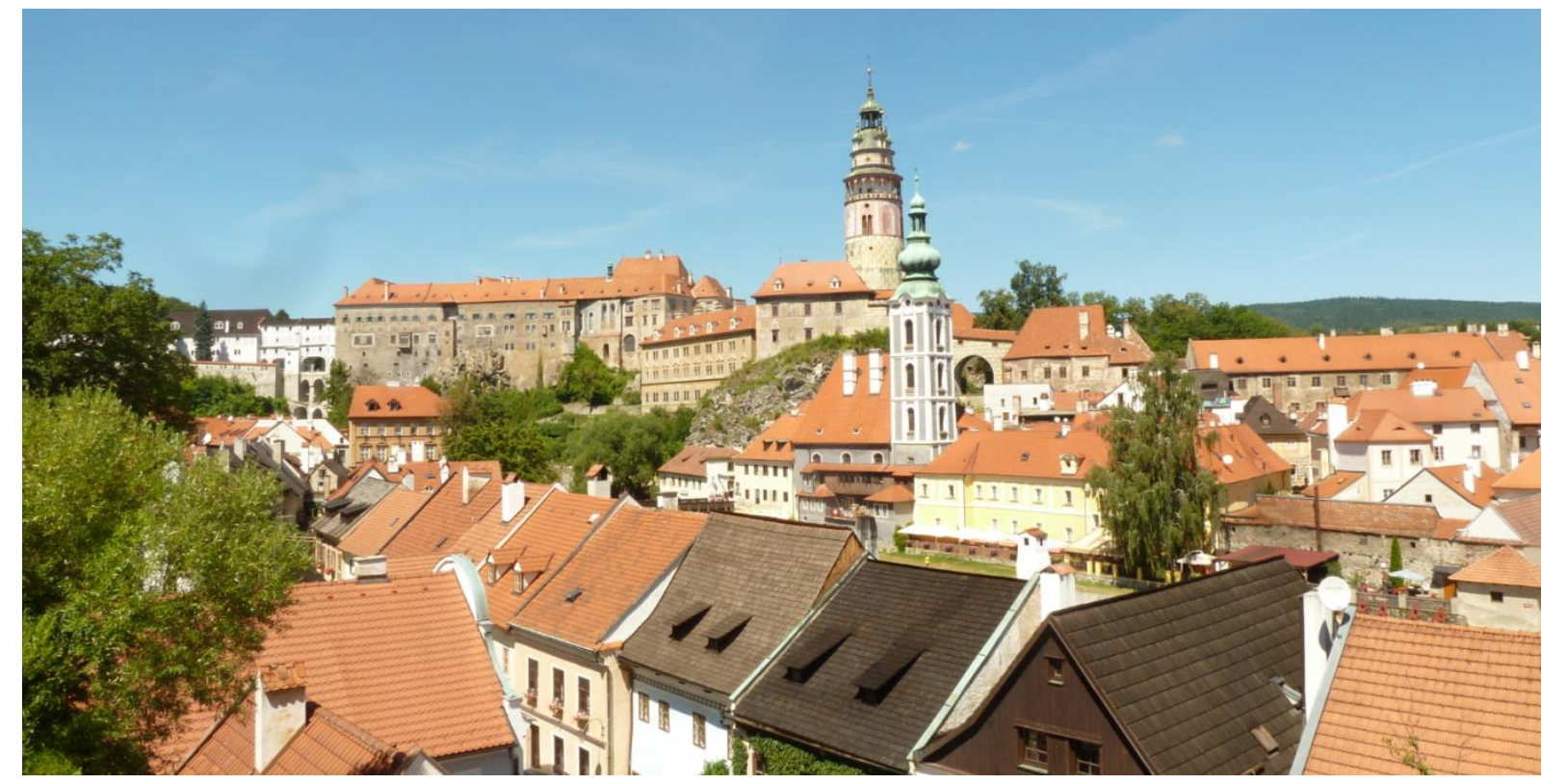

Fig 3. Český Krumlov (Jihočeský Region), internationally known centre of tourism and UNESCO World heritage site since 1992. Photo A. Vaishar

By such a way one regionalization and four dimensions of typology of small towns were elaborated. The combination of size, regional position, accessibility and functions will result in a typology of the Czech small towns. The aim consists in searching for regularities and relations between individual types of small towns and indicators of sustainability. The next step consists of an analysis of the sustainability of individual types of small towns. The sustainability of small towns was defined e.g. by Knox and Mayer (2009) as a normative view combining environmental sustainability with notions of economic growth and social justice. They highlight that people generally perceive rather unsustainability like structural economic decline, environmental degradation, outmigration, segregation, exclusion, antisocial behaviour and loosing of sense of place. This is why we use available statistical data about demography, employment and education to characterize different dimensions of sustainability.

Demographic sustainability has been evaluated on the base of data about natality, mortality, inmigration and outmigration for each of the set of the small towns. The last 5 years (2010 - 2014) were taken into account. Although the database provides data since 1971 annually and every ten years since 1869, the trends changed in history and the results could conceal the real development. Moreover, our interest is with the recent development Migration is considered to be a decisive indicator because it is connected with the attractiveness of the town.

Economic sustainability has been measured on the base of unemployment rate. The data are available from the Ministry of Labour and Social Affairs. The data relate to May 2015, it means to the months without bigger deflections. We assume that the unemployment rate indicates more or less stability and prospects of micro-regional economic base.

Social sustainability can be evaluated by the educational structure. It is an indicator substituting the social status of the population because data about average incomes or tax payers are not available for individual municipalities. We assume that more educated social strata are socially 
higher (e.g. upper middle class or middle class), although in individual cases it may not be. The data are taken from the population census 2011.

\section{Typologies of Czech small towns}

The goal of the typologies consists of the creation of a base for further statistical comparison of the small towns set. The questions: Which typology allows to explain most differences in the sustainability of small towns and which characteristics are most illustrative for individual types of small towns?

\subsection{Size of small towns and their regional peculiarities}

Of the whole set of 283 small Czech towns, 55 belongs to the A size category, 117 to the B size category and 111 to the $\mathrm{C}$ site category (Fig. 4). The whole set of the towns was divided into six regional groups (Table 1) which contain similar numbers of small towns.

Tab 1. Regional overview of Czech small towns and their size (own calculations based on the 2011 population census).

\begin{tabular}{|l|c|c|c|c|}
\hline Region / Inhabitants & $\mathbf{3 , 0 0 0 - 4 , 9 9 9}$ & $\mathbf{5 , 0 0 0 - 8 , 9 9 9}$ & $\mathbf{9 , 0 0 0}-\mathbf{1 4 , 9 9 9}$ & Total \\
\hline Central Bohemia & 6 & 10 & 13 & 29 \\
\hline Hinterland of Prague & 2 & 7 & 6 & 15 \\
\hline South-west Bohemia & 7 & 20 & 23 & 50 \\
\hline North-west Bohemia & 8 & 17 & 22 & 47 \\
\hline North-east Bohemia & 13 & 24 & 11 & 48 \\
\hline South Moravia & 8 & 18 & 20 & 46 \\
\hline Central and Northern Moravia & 8 & 12 & 13 & 33 \\
\hline Silesia & 3 & 9 & 3 & 15 \\
\hline Altogether & $\mathbf{5 5}$ & $\mathbf{1 1 7}$ & $\mathbf{1 1 1}$ & $\mathbf{2 8 3}$ \\
\hline
\end{tabular}

The first striking findings is that the number of the largest small towns (A size) can be found in traditional industrial regions in northern parts of the country whereas the biggest numbers of small towns of the $\mathrm{C}$ size are in typical rural regions of south-western Bohemia and southern Moravia. Only north-western Bohemia defies from the rule as an industrial area with a prevalence of small towns of the $\mathrm{C}$ size. The reason is that there are many towns which only fractionally cross the population limit for our study in this region.

It is clear that the district towns (those of them which are classified within small towns) belong mostly to the A size category. There is no district town in the category of small towns in Moravia. Additionally, there are 118 small towns among the municipalities with extended competences ${ }^{7}$.

\footnotetext{
7 District offices were cancelled during the last administrative "reform" of the Czech Republic (the districts remained as statistical, judicial and similar units or branches of various regional institutions). However, it was obvious that the gap between regions and often very small municipalities should be filled. That is why a special unsystematic solution was accepted. The offices with extended competence perform administrative functions for small municipalities which are not efficient or even possible to realize there. Small municipalities are not subordinated to the municipalities with extended competences but they depend on them. On the other hand, municipalities with extended competences perform important functions for small municipalities but their councils are not elected by the inhabitants of small municipalities.
} 


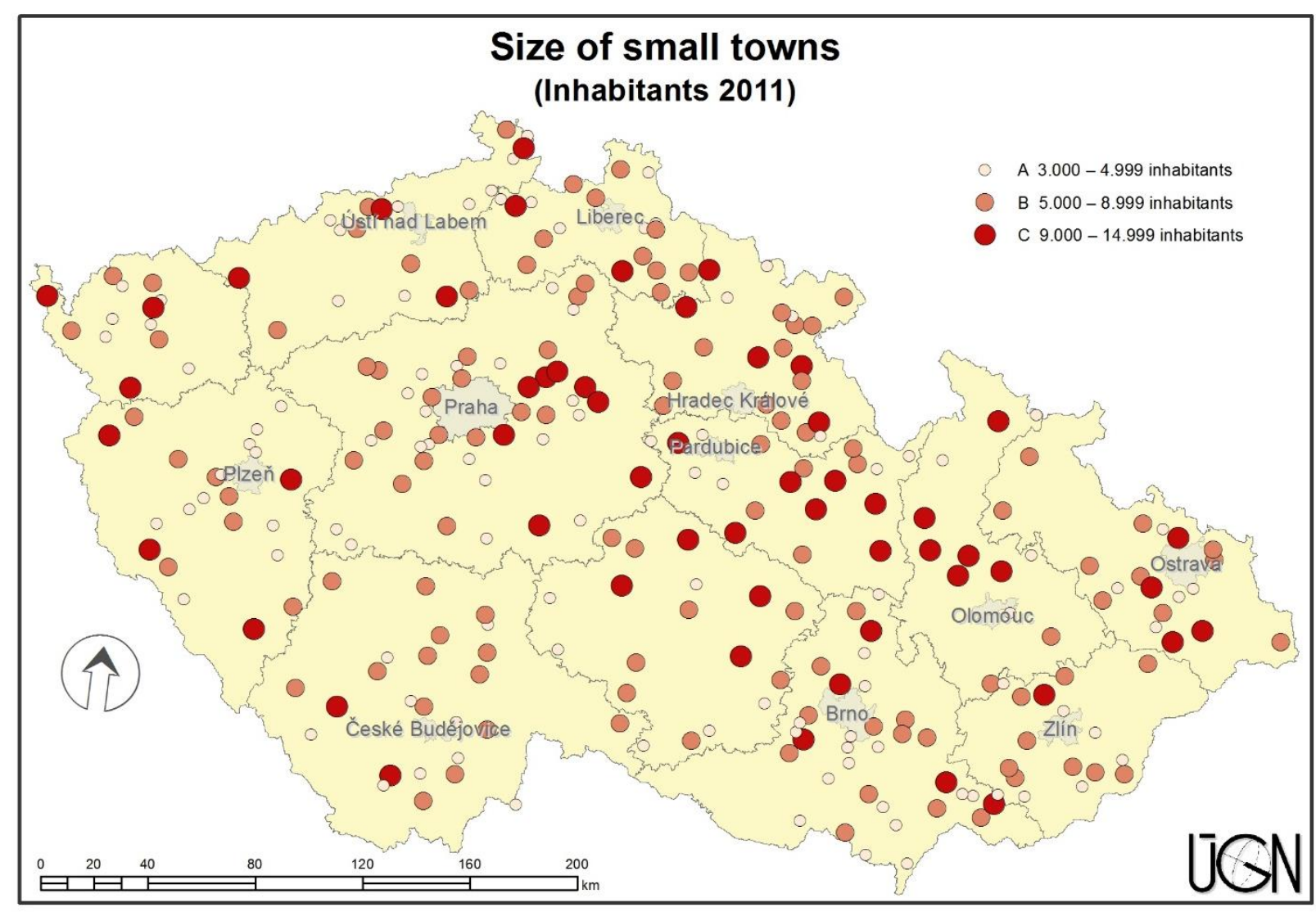

Fig 4. Small towns by size class. Source: Population census 2011. Czech Statistical Office Praha. Drawn by E. Nováková

\subsection{Accessibility}

The following classes of small towns according to the accessibility of the closest regional centre were defined: below 25 minutes [1], 25 - 34 minutes [2], 35 - 44 minutes [3], 45 - 59 minutes [4] and 60 minutes and more [5]. It is more or less clear that this indicator is of geographical character (combined with the organization and maintenance of the road network). It shows that understandably small towns in the hinterland of Prague have the most favourable situation in accessibility - although the category of small towns with most advantageous accessibility is more frequent in south-west Bohemia. Surprisingly the biggest share of small towns with the worst accessibility is observed in north-eastern Bohemia (especially in its north-eastern corner) and in north-west Bohemia (partly due to the fact that Karlovy Vary has not been included among regional centres). South Moravia has the most evenly situated small towns.

The time distances were calculated always to the core of the regional centre (Fig. 5). In such a case the small towns in the hinterland of Prague are disadvantaged because many times the majority of the ride accounts for overcoming the distance between the fringe and core of the city. The cores of other regional centres are accessible more easily. Another aspect of the situation is the fact that the people could use the route which is not the shortest in time but the shortest in distance or easier to drive. However, the main methodological problem consists in earmarking of regional centres. 
Tab 2. Regional overview of Czech small towns and their accessibility (in minutes) from closest regional centre (own calculations based on Seznam.cz maps).

\begin{tabular}{|l|c|c|c|c|c|}
\hline Region & $\begin{array}{c}\text { less than } \\
\mathbf{2 5} \text { } \mathbf{~ i n ~}\end{array}$ & $\begin{array}{c}\mathbf{2 5} \mathbf{- 3 4} \\
\text { min }\end{array}$ & $\begin{array}{c}\mathbf{3 5} \mathbf{- 4 4} \\
\text { min }\end{array}$ & $\begin{array}{c}\mathbf{4 5} \mathbf{- 5 9} \\
\text { min }\end{array}$ & $\begin{array}{c}\mathbf{6 0} \text { min } \\
\text { and more }\end{array}$ \\
\hline Central Bohemia & 0 & 8 & 10 & 10 & 1 \\
\hline Hinterland of Prague & 5 & 6 & 4 & 0 & 0 \\
\hline South-western Bohemia & 14 & 12 & 5 & 7 & 10 \\
\hline North-western Bohemia & 6 & 6 & 13 & 8 & 15 \\
\hline North-eastern Bohemia & 7 & 6 & 6 & 15 & 14 \\
\hline Southern Moravia & 10 & 10 & 8 & 9 & 9 \\
\hline Central and Northern Moravia & 8 & 9 & 9 & 6 & 1 \\
\hline Silesia & 5 & 3 & 1 & 3 & 3 \\
\hline
\end{tabular}

Firstly, the individual centres are not comparable: Prague forms the first level, Brno (maybe with Ostrava and Plzeň) the next, other centres the third one. The accessibility of Prague has a different significance than the accessibility of e.g. Pardubice. And of course, there are cities which we did not earmarked but if we did so, the values of accessibility in their vicinity would change substantially (Karlovy Vary, Jihlava, Opava). Nevertheless we tried to proceed according to our long term experience. Mentioned aspects should be discussed in individual cases when qualitative aspects are taken into account.

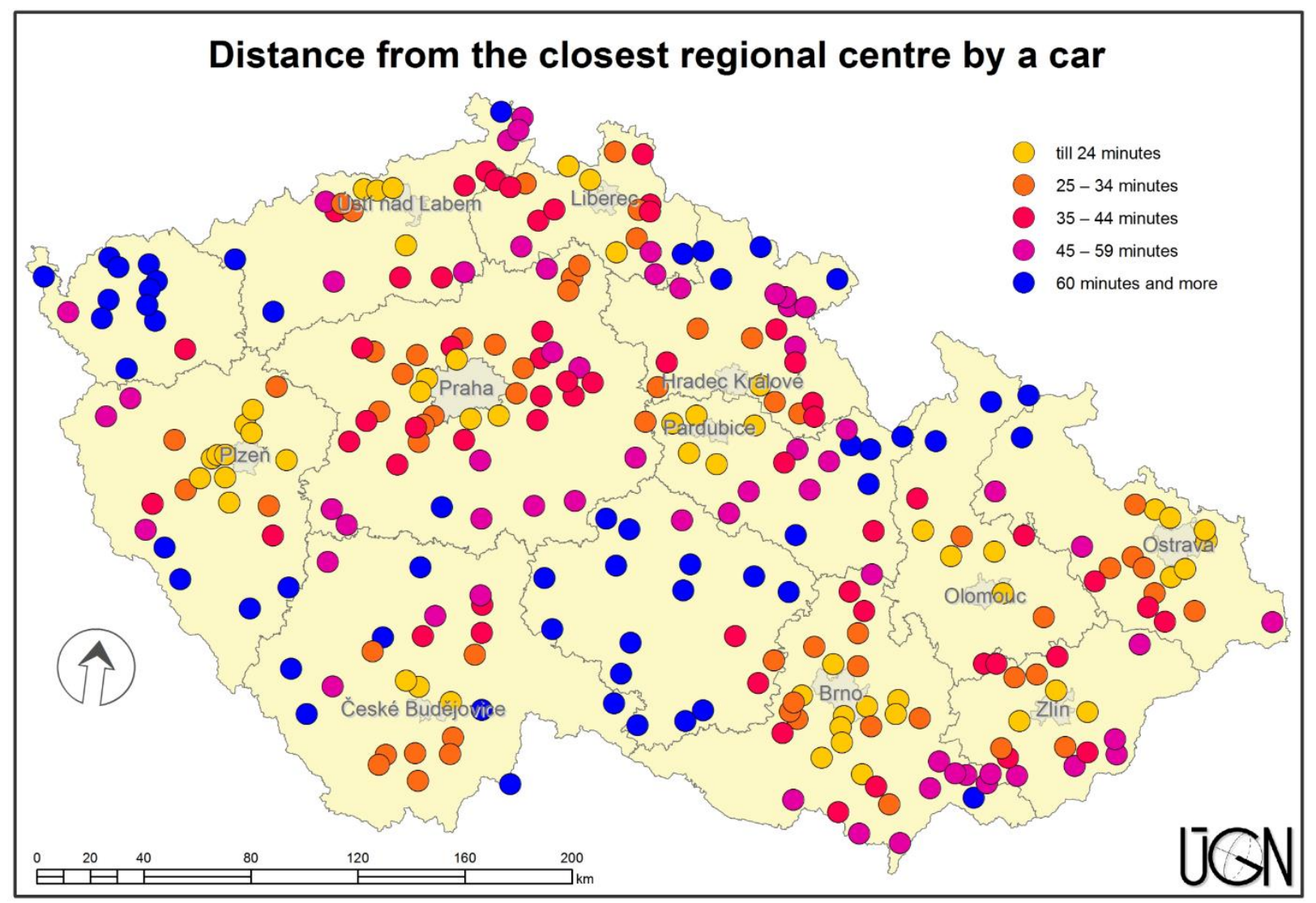

Fig 5. Distance from the closest regional centre by a car. Source: Seznam.cz/maps. Drawn by E. Nováková 


\subsection{Functions in economy}

Small towns with an over-average employment in the primary sector can be found mostly in rural regions in South and Central Moravia, Vysočina, South-west Bohemia and in the Labe and Ohře basins. Small towns with over-average industrial employment are situated mostly in the borderland of Northern Bohemia, in the vicinity of big cities excluding Prague and in Eastern Moravia (Fig. 6).

The occurrence of small towns with commercial services is typical for the surroundings of Prague, to a smaller extent also for the vicinity of other big cities whereas present and past district towns belong often to the small towns with over-average employment in social services. Small towns with an over-average orientation to tourism contain traditional resorts of winter tourism and spas. Their concentration is observed in the borderland mountain ranges and especially in the Karlovy Vary region.

Regionally, Central Bohemian Region has small towns of both commercial and social services, South-west Bohemia small towns oriented towards the primary sector, tourism and in the vicinity of Plzeň also for industry. Small towns of North-west Bohemia are mostly industrial with some share of towns with tourism and commercial services. The same is true for North-east Bohemia where some agricultural small towns are added. Small towns of Vysočina region are oriented almost completely towards the primary sector, while small towns of Southern Moravia are also agricultural with some cases of small towns with industry and commercial service in the vicinity of Brno. The remainder of Moravia and the Czech part of Silesia has a mixture of small towns oriented towards agriculture, industry, tourism and commercial services.

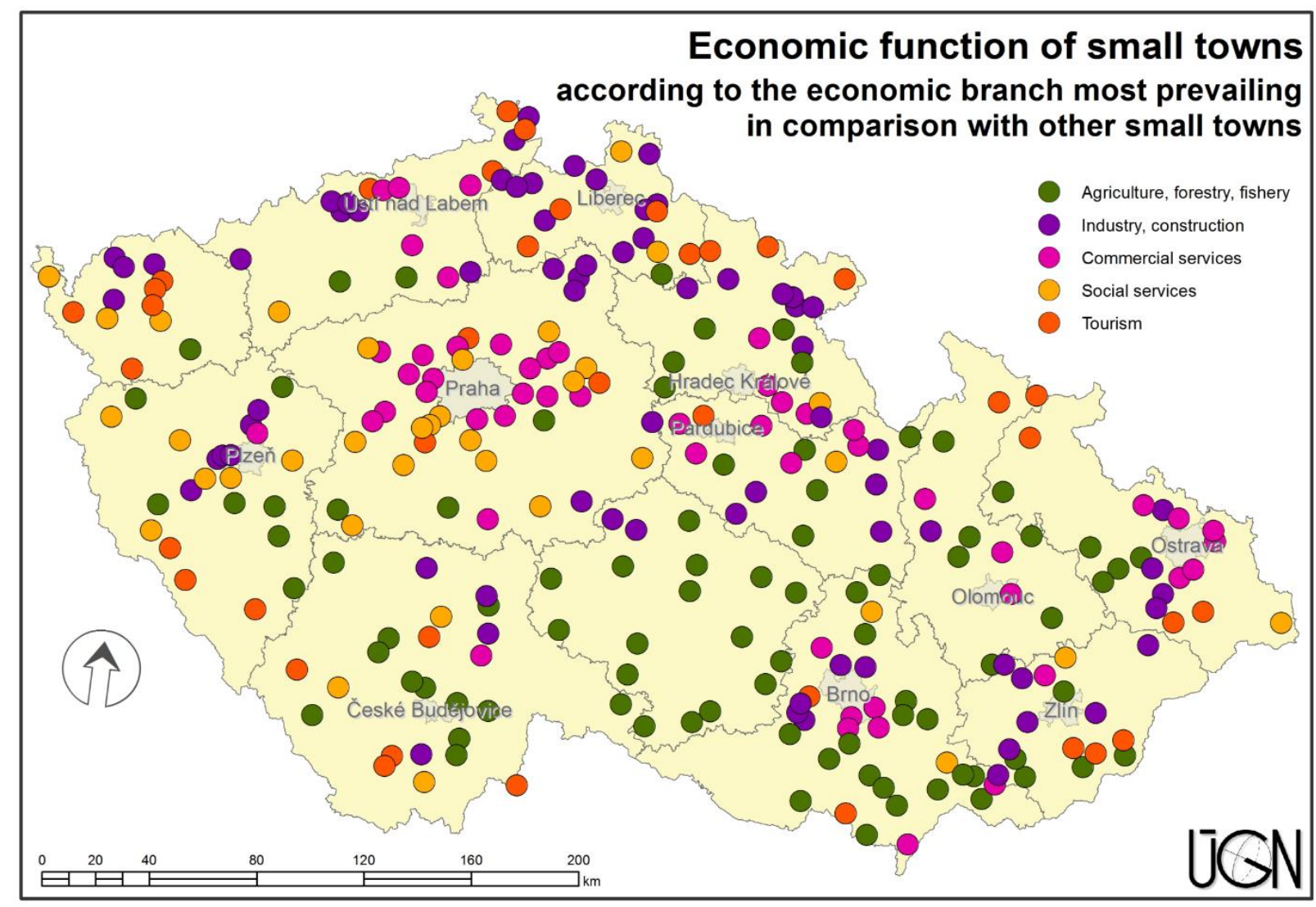

Fig 6. Economic functions of small towns. Source: own calculations according to Population census 2011. Drawn by E. Nováková

\subsection{Functions in labour market}

Small towns which are important centres of job opportunities are dispersed across the Czech territory. Some concentration is seen rather in cases of small towns without central function in the job market, such as small towns with a balanced number of jobs and an economic active population and small towns depending in the case of jobs on other centres, it means preliminary 
residential small towns). Logically, residential small towns can be found in the vicinity of Prague and Ostrava, to a lesser extent in the surroundings of other big cities. Additionally, a big number of such towns is concentrated in North-Western Bohemia. It seems to be typical for (former) mining regions where jobs are concentrated in other sites than in cities and towns (Fig. 7).

On the other hand some small towns with an expressive job function can be found in the surroundings of Brno where they cooperate with the metropolis in the job distribution and in the space between the East Bohemian twin cities Hradec Králové - Pardubice and the central Moravian metropole Olomouc where bigger towns are missing and thus small towns have to substitute them.

The highest number of jobs for surrounding municipalities offers Modřice (6,900 jobs over the necessity of the own inhabitants). However in this special case, the majority of commuters to Modřice come from Brno. Kuřim near Brno (4,000 jobs over the own necessity) is a similar case. Big centres of job opportunities for surrounding rural areas are district towns Nymburk, Domažlice, Ústí nad Orlicí and the former district towns Turnov or Boskovice.

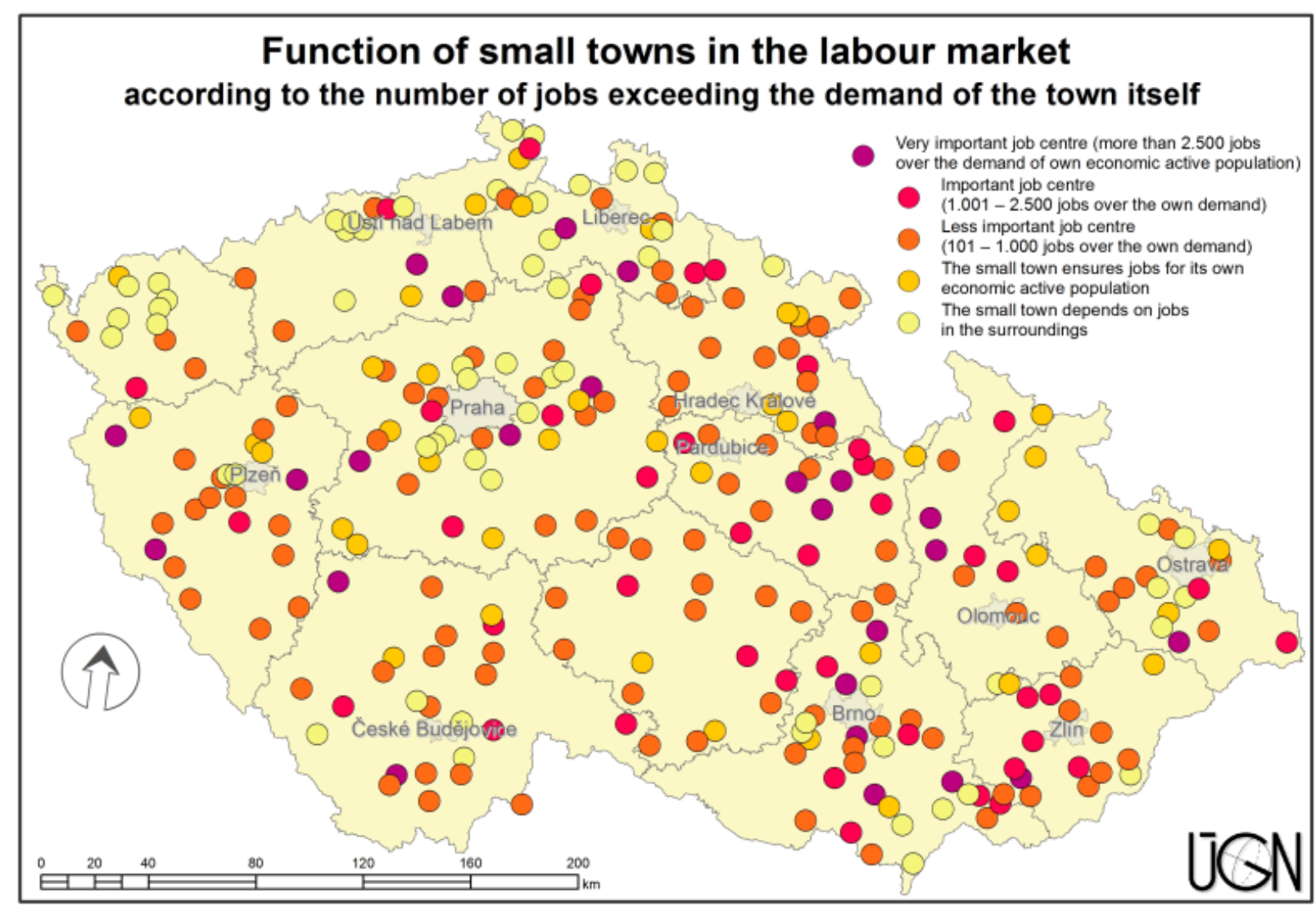

Fig 7. Functions of small towns in the labour market. Source: Ministry of Finance of the Czech Republic. Drawn E. Nováková

\section{Sustainability of the Czech small towns}

The sustainability consists of three pillars: environmental, economic and social ones (Hansmann et al., 2012). For the purpose of this paper, these three pillars were operationalised by indicators measuring the demographic development, (un)employment and educational level. Methodologically the question of evaluation should be discussed. It is hardly possible to state which level of education, unemployment or population balance is still sustainable. That is why the method of comparison is used. From it follows that the results could be interpreted by such a way that some towns are more sustainable than others.

\subsection{Demographic sustainability (population development)}

Both natural development and migration were statistically evaluated for the whole set of small towns. Data from the five-year period 2010 - 2014 were used (Fig. 8). It is more or less clear that 
small towns with a more progressive demographic development can be found in the hinterland of big cities - mostly Prague, then Brno and in some cases also of the other ones (e.g. České Budějovice). It is possible to speak about sub-urbanized small towns to which young families in reproductive age move. By such a way the in-migration is followed by the natural increase as a rule.

On the other hand, a significant decrease of the population number manifests preliminary in peripheral small towns. Especially young educated people who cannot find sufficiently prestigious job in small towns move out. By such a way, out-migration is followed with the natural decrease. In general, it seems that the demographic sustainability closely relates to the distance from the most important regional centres where the vicinity of less important regional centres contains small towns with stagnation or even population decrease.

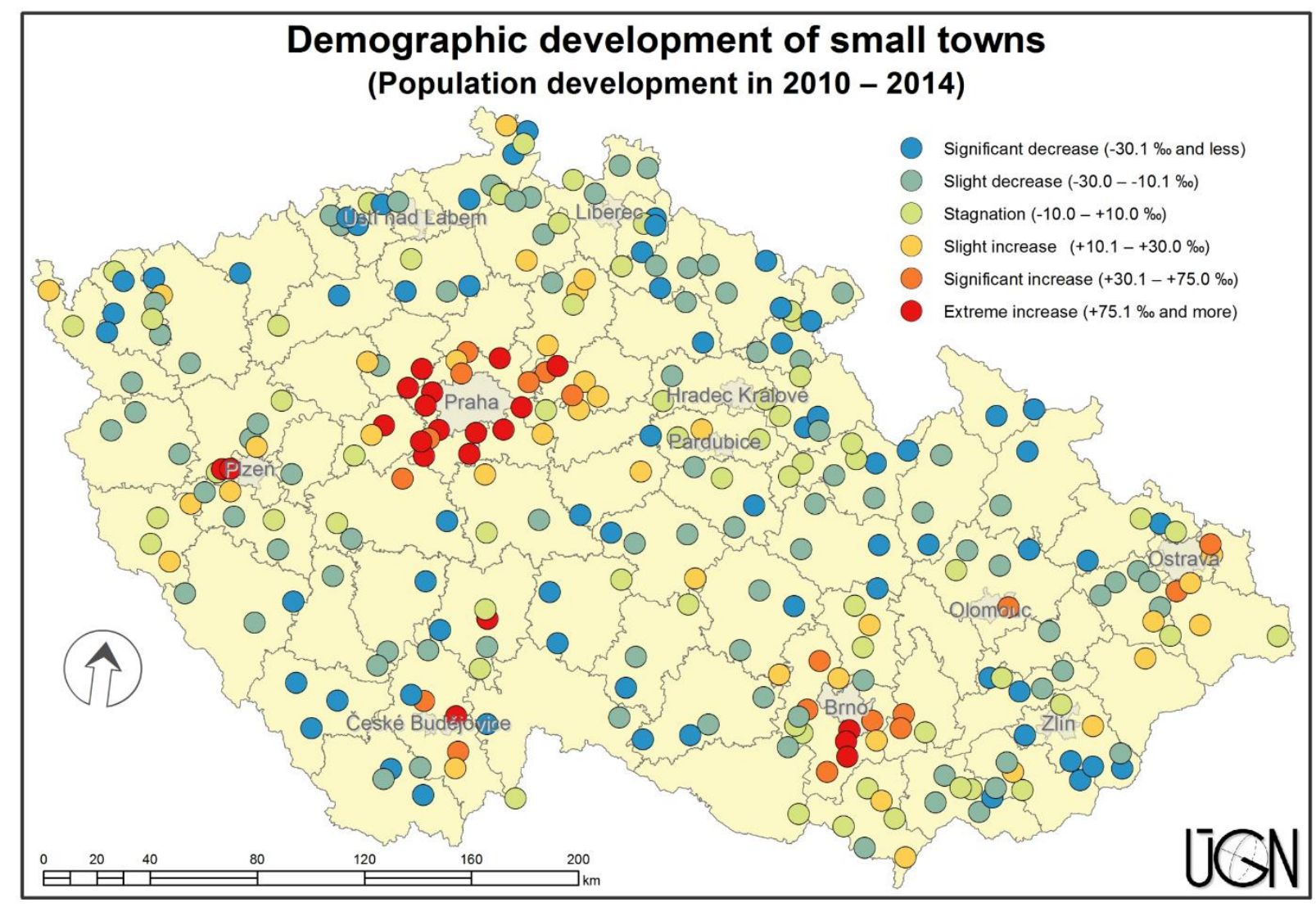

Fig 8. Demographic development of small towns (2010 - 2014). Source: population balances. Czech Statistical Office Praha. Drawn by E. Nováková

\subsection{Economic sustainability (unemployment)}

Unemployment data were used from May 2015. This period can be considered as a post-crisis time when the unemployment decreased. The spring is generally characterized by a situation when the consequences of resignations at the end of the preceding year are mostly resolved, part of seasonal workers (mainly in construction industry) is employed but seasonal workers in agriculture and tourism are still waiting for jobs and future graduates are still at schools. The national average was $5.4 \%$.

Small towns with highest unemployment rates can be found in north-western Bohemia with biggest structural changes (transition from heavy industry and coal mining), partly also in some parts of Moravia and Silesia (Fig. 9). The highest unemployment is observed in Ústecký region in the districts Děčín, Most, Litoměřice and Louny. The highest unemployment was recorded in Postoloprty (12.6\%).

On the other hand, the lowest unemployment rate is typical for small towns in the vicinity of big towns (Prague, Brno and others), in the Czech-Bavarian borderland and also in some parts of Eastern Bohemia. There are 9 small towns with an unemployment rate below 3\% (the best of 
them is Kostelec nad Černými lesy, with the unemployment rate of $0.8 \%$ ). They are situated in the surroundings of Prague, České Budějovice and Plzeň. In most cases, jobs are not situated in these small towns but rather commuting is needed.

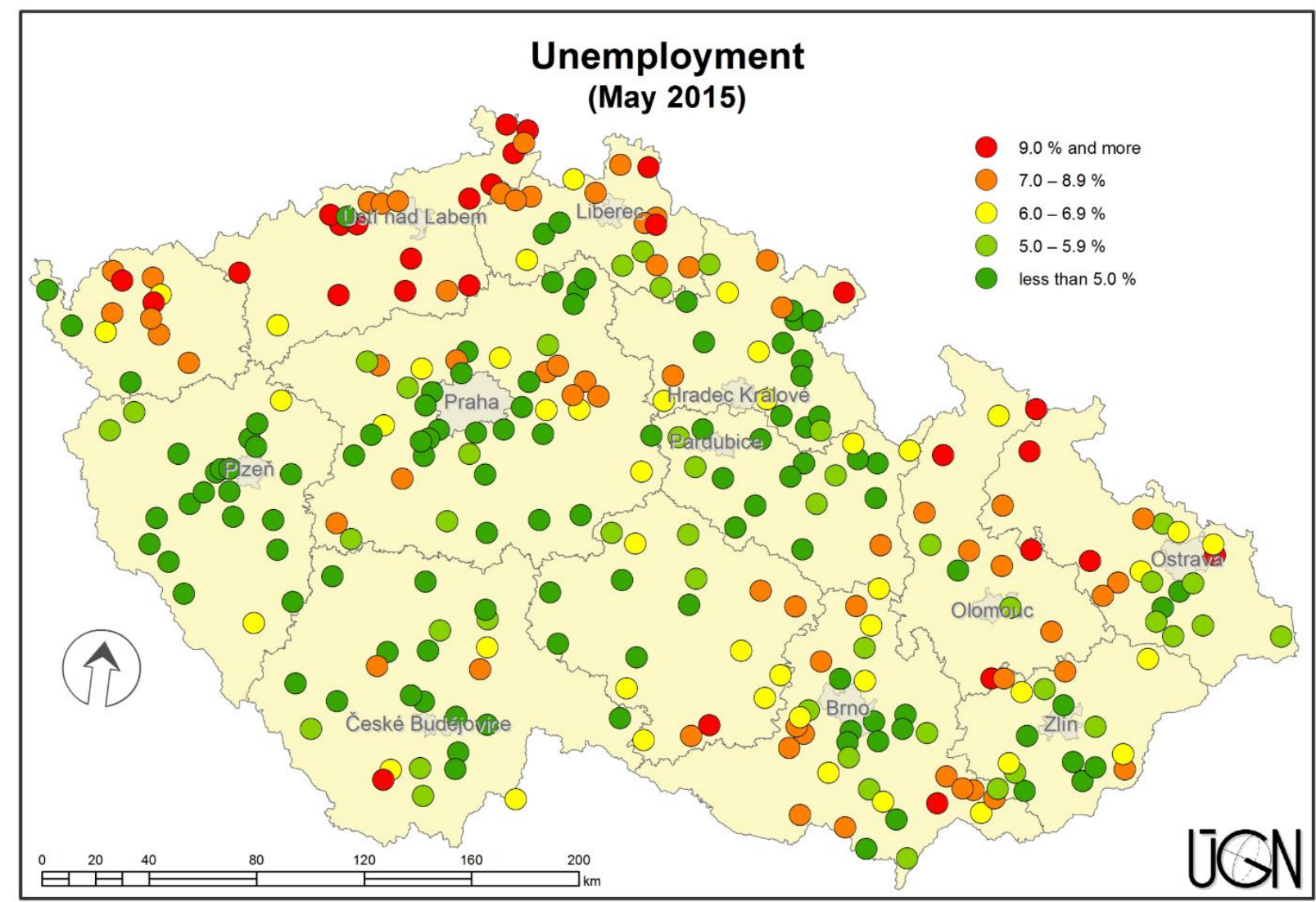

Fig 9. Unemployment rate in May 2015. Source: Ministry of Labour and Social Affairs of the Czech Republic. Drawn by E. Nováková

\subsection{Social sustainability (education level)}

The highest share of people with higher than secondary education can be observed in the vicinity if big cities (Prague and the whole Central Bohemia, surroundings of Brno). Relatively high education level can be found also in Eastern Moravia. It is obvious that Moravian small towns have better educated population than Bohemian ones (except of Prague and its surroundings). Of 9 small towns with higher than $20 \%$ share of university educated inhabitants, all are situated in the surroundings of Prague. Among other towns with a higher share of university educated (15 - 20\%) are spas (Poděbrady, Lázně Bohdaneč), some small towns in the surroundings of Brno and individual cases in the vicinity of České Budějovice and Olomouc (Fig. 10).

The lowest share of the university educated people can be found in small towns of north-western Bohemia (industrial regions of Karlovy Vary, Ústí nad Labem and Liberec) and individually also in other regions often in the borderland. The Bohemian-Moravian borderland represents some average situation. The share of university educated people decreases in 28 small towns under $5 \%$. The most formally uneducated inhabitants recorded Rotava (district Karlovy Vary) where only $2.1 \%$ inhabitants with higher education live. The only small town in this group in Moravia is Hanušovice $(4.0 \%)$. All others are situated in the Bohemian part of the country. 


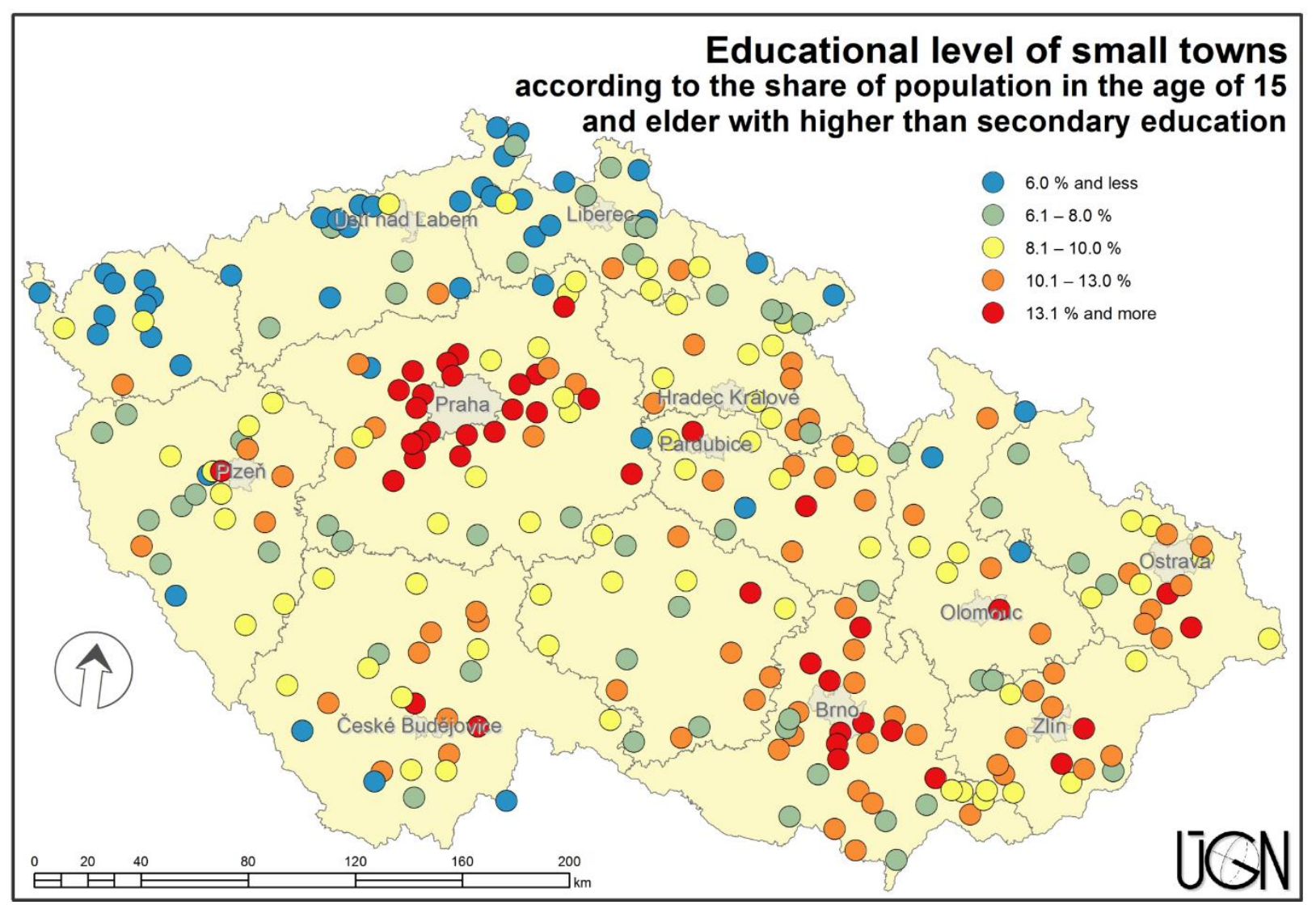

Fig 10. Education level in small towns. Source: Population census 2011. Czech Statistical Office Praha. Drawn by E. Nováková.

\subsection{General evaluation}

The analytic results are summarized in Table 3 . It can be stated that the best demographic situation is in the surroundings of Prague, in Central Bohemia (what relates with the foregoing) and (much less) in Southern Moravia. Depopulation tendencies are found in the small towns of North-East and North-West Bohemia, in Central Moravia and Silesia. Population development worsens with increasing size of small towns, with increasing distance from regional centres and in productive small towns (more in industrial than in agricultural ones). Small towns with balanced job markets and dependent on jobs in other places have better demographic perspectives.

The highest education level is observed in the surroundings of Prague which relates to the suburban zone of capital; Central Bohemian and Moravian small towns follow. Small towns on the fringe of the Bohemian settlement system lag behind. The Bohemian-Moravian gradient is quite interesting and could hypothetically relate to the historical background or to the role of Prague which attracts educated people from all other Bohemian areas. Understandably, the education level decreases with the distance from regional centres. There is no wonder that the best education level is found in small towns with both production and social services whereas small towns with productive function and tourism have a less educated population. Similarly important job centres have higher level of education than other small towns.

Unemployment has no relation to the size of small towns. Small towns in vicinity of regional centres have a slightly lower level of the unemployment that the peripheral ones. Small towns with a tourist function show the highest level of unemployment. Moreover, unemployment uses to be a seasonal problem there as a rule. Productive small towns follow. Small towns of social services are on the opposite side. Here the employment is not so directly connected with crises. 
Tab 3. Indicators of sustainability in small towns. Source: own calculation.

\begin{tabular}{|c|c|c|c|}
\hline Type of small towns & $\begin{array}{l}\text { Demographic } \\
\text { development in } \\
\% \text { (2010-2014) }\end{array}$ & $\begin{array}{l}\text { Unemployment } \\
\text { rate }(5 / 2016)\end{array}$ & $\begin{array}{l}\text { Share of people } \\
\text { with tertiary } \\
\text { education (2011) }\end{array}$ \\
\hline \multicolumn{4}{|l|}{ According to region } \\
\hline Central Bohemia & 38.9 & 5.6 & 10.6 \\
\hline Surroundings of Prague & 92.2 & 3.6 & 19.9 \\
\hline Southern and Western Bohemia & -3.5 & 4.7 & 8.7 \\
\hline North-Western Bohemia & -20.5 & 8.1 & 5.9 \\
\hline North-Eastern Bohemia & -18.6 & 5.1 & 9.3 \\
\hline Southern Moravia & 4.8 & 6.4 & 10.7 \\
\hline Central Moravia & -13.7 & 6.4 & 10.3 \\
\hline Silesia & -14.7 & 7.5 & 9.3 \\
\hline \multicolumn{4}{|l|}{ According to the size } \\
\hline Smallest small towns & 2.9 & 6.0 & 8.8 \\
\hline Medium-sized small towns & 0.7 & 6.0 & 10.0 \\
\hline Big small towns & -5.9 & 5.9 & 10.9 \\
\hline \multicolumn{4}{|l|}{ According to the accessibility } \\
\hline Small towns closest to regional centres & 29.1 & 5.0 & 12.1 \\
\hline Small towns close to regional centres & 13.6 & 5.7 & 10.5 \\
\hline Small towns in a medium distance & -3.5 & 6.4 & 9.8 \\
\hline Distanced small towns & -12.6 & 6.2 & 8.7 \\
\hline Most distanced small towns & -25.5 & 6.5 & 7.5 \\
\hline \multicolumn{4}{|l|}{ According to the economic function } \\
\hline Agricultural small towns & -11.9 & 6.1 & 9.3 \\
\hline Industrial small towns & -15.8 & 6.2 & 7.7 \\
\hline Small towns of production services & 40.2 & 5.9 & 11.9 \\
\hline Small towns of social services & 6.6 & 5.4 & 11.6 \\
\hline Small towns of tourism & 6.6 & 6.6 & 9.0 \\
\hline \multicolumn{4}{|l|}{ According to the job offer } \\
\hline The most important job centres & 0.1 & 5.4 & 11.9 \\
\hline Important job centres & -7.0 & 5.7 & 11.1 \\
\hline Job centres & -4.4 & 5.7 & 9.6 \\
\hline $\begin{array}{l}\text { Small towns with jobs for their own } \\
\text { population }\end{array}$ & 7.9 & 6.4 & 8.5 \\
\hline $\begin{array}{l}\text { Small towns depending on centres as } \\
\text { concerns jobs }\end{array}$ & 8.3 & 6.7 & 9.0 \\
\hline
\end{tabular}


It could be concluded that there are some relations between small town types and sustainability indicators. The majority of relations were expected, some of them are more or less surprising. However, the majority of indicators origin from official statistic data (which is the only possibility taking into account the whole set of the Czech small towns). From it follows that the results depend on data availability and relevancy and also on territorial delimitation of small town's territories. It is necessary to bear this in mind especially by evaluating individual small towns.

\section{Discussion: Which small towns are sustainable?}

It seems that the most sustainable small towns are those which are situated in the vicinity of Prague (or other regional centres), with over-average employment in services and the most important job centres. On the other hand, the least sustainable are small towns in north-west Bohemia, far from regional centres with over-average employment in manufacturing industry. Small towns in Moravia, medium-sized job centres in a medium distance from regional centres with an over-average employment in agriculture (typical towns of Moravian lowlands) and manifest some average category. However, is this really the case?

Taking into account past experience, it is possible to express another standpoint. As concerns the first category (centres in close vicinity of regional centres), their development seems to be too rapid. Some of them are more or less mono-functional. Their future depends on keeping the main function or on developing a new one. Their focus on services looks hopefully if it is their own activity - not the result of commuting into the regional centre. So the future of these small towns will be probably different.

On the other hand, peripheral small towns have broadly the worst characteristics of individual indicators. They are shrinking, ageing, losing the most educated people, out of economic development and political lobbying, being stigmatized in media etc. (Kühn 2015). However, peripheral small towns will mostly be always important centres of their rural hinterland because there is no competition in their vicinity and, usually, the difficult transport situation (dissected relief) does not allow commuting into more distanced bigger centres.

Small towns of Moravian lowlands seem to be an average category. Nevertheless, easy throughput of these territories exposes them to the competition among each other and also of bigger towns. It seems that some specialization (usually in the service sector: tourism, education, health and social care or in special industry) is the most promising way of their future prosperity.

It is possible to conclude that the situation of small towns in the Czech territory is and will be differentiated depending on their geographical position. Within the categories of suburban, intermediate and peripheral small towns individual characteristics seem to be decisive. Human and social capital, their attracting and retaining is the most important factor.

Small towns are often considered as pleasant places for living taking into account their closeness to nature, higher personal security etc. According to Mainet (2015) of all three pillars of sustainability, the economic one seems to be less important in residential choices and mobility.

In our opinion, the existence of small towns is not threatened in the near future. The question is whether the character and functions of small towns will sustain. To answer the question from the title of the paper let us assume that in fact not the sustainability indicators measured but rather the position of small towns in the settlement system is the most important. Those small towns which are unequivocal centres of rural hinterland will play their role also in future keeping their urban/rural character (despite of sometimes decreasing population numbers). It concerns firstly the peripheral small towns. Fertner et al. (2015) discuss some successful developments of those small towns on the Danish examples which are not in favourable geographical positions. Our research found successful small towns in peripheral positions, especially in western Bohemia. However, these towns are peripheral from the national viewpoint. Taking into account the vicinity of the Bavarian border, their peripherality from the European viewpoint should be re-evaluated. Other peripheral small towns are sometimes successful according to individual indicators (mostly unemployment or educational level), but not in their entirety. Although theoretically some path dependency, activity of local stakeholders and other individual factors should play their role, it 
becomes obvious that the geographical position regarding to the vicinity and accessibility of regional centres is important for small town development in general.

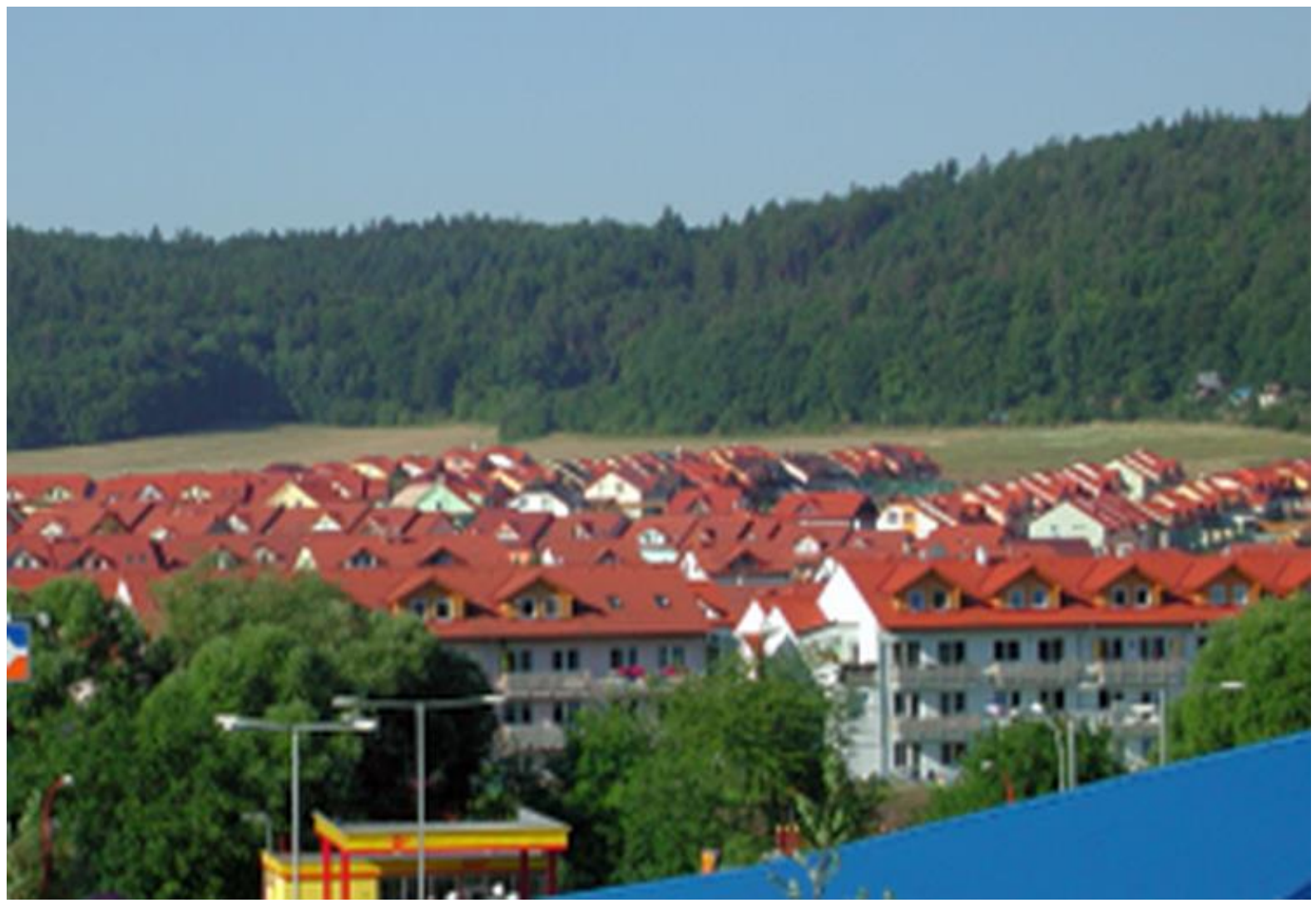

Fig 11. Kur̆im (Jihomoravský Region): a suburbanized small town in the vicinity of Brno. Photo A. Vaishar

The question is who takes care for the development of small towns. Servillo et al. (2013) show that small towns are objects of either regional (spatial, territorial) or rural policy as a rule. However, they are usually not objects of a specific attention. Moreover, the rural policy is aimed mostly at agriculture - although formally the multifunctional countryside is highlighted. In the Czech case, small towns are mostly no rural towns aimed at a retail of agricultural surplus and supply of farmers with necessary services but distinctive historical centres with a strong industrial function. They often dispose with a specific spirit of the place (genius loci). It seems that small towns need a place-based policy focused on the versatile rural development which would clarify their role in the settlement system.

\section{Conclusion}

There is no doubt that the small town sector is a very important segment of national settlements systems. They represent a rural milieu with basic urban services which could be attractive for many people. It is possible to expect that the importance of small towns will be kept or even increase in connection with contemporary urbanization processes, with technological changes connected with transformation from industrial to the post-industrial society (continuing shift to the culture and leisure activities; Lorentzen and van Heur 2012) and also with increasing importance of personal security of people. Sometimes the cultural heritage of small towns can be considered as a driving force of local development (Lazzeroni et al. 2010). One of the future questions should be whether internet technologies could change the peripherality of the most distanced small towns by teleworking and easier general communication (see e.g. Collins 2010).

That is why the future development of small towns in their diversification should be investigated taking into account both the whole sector and individual cases. Kobojek and Marshal (2014) see the future of small towns in redefining their role in the regional structure through finding new opportunities for growth and for improvement of local communities' living conditions. In this article, 
quantitative statistical data were used. However, such questions ask for qualitative investigations by using sociological methods. Possible impacts of international migration on small towns should be also discussed in the future (see Fonseca 2008) as well as impacts of (economic) globalization and digital communication.

\section{Acknowledgement}

The research was supported by long-term conceptual development support of research organisation (Institute of Geonics of the Czech Academy of Sciences) RVO: 68145535.

References

[1] Bell, D., Jayne, M. (2009). Small cities? Towards a research agenda. International Journal of Urban and Regional Research 33(3), 683-699. DOI: 10.1111/j.1468-2427.2009.00886.x.

[2] Besser, T. (2013). Resilient small rural towns and community shocks. Journal of Rural and Community Development 8(1), 117-134.

[3] Belova, A. V., Levchenkov, A. V. (2012). Innovation centres as growth points for smaller towns and rural areas. Baltic Region 4(3), 388-397. DOI: 10.5922/2079-8555-2012-3-8.

[4] Borsdorf, A., Paal, M. (2000). Die „Alpine Stadt“ zwischen lokaler Verankerung und globaler Vernetzung. Wien: Verlag der Österreichischen Akademie der Wissenschaften.

[5] Borsig, A., Burdack, J., Knappe, E. (2010). Small towns in Eastern Europe: local networks and urban development. Leipzig: Leibniz-Institut für Länderkunde.

[6] Burdack, J., Kriszan, A. (2013). Kleinstädte in Mittel- und Osteuropa: Perspektiven und Strategien lokaler Entwicklung. Leipzig: Leibnitz-Institut für Länderkunde.

[7] Bürk, T. (2013). Voices from the margin: the stigmatization process as an effect of sociospatial peripheralization in small-town Germany. In Fischer-Tahir, A., Naumann, M., eds., Peripheralization (pp. 168-186). Wiesbaden: Springer VS.

[8] Capel, H. (2009). Las pequeñas ciudades en la urbanización generalizada y ante la crisis global. Investigaciones geográficas Vol. 70, p. 7-32.

[9] Cigale, D., Lampič, B., Ogrin, M., Plut, D., Rebernik, D., Špes, M., Vintar Mally, K., Cetkovský, S., Kallabová, E., Mikulík, O., Vaishar, A., Zapletalová, J. (2006). Sustainable development of small towns a Slovenian-Moravian comparative methodological approach. Moravian Geographical Reports 14(1), 17-28.

[10] Collins, J. L. (2010). Small town in the internet society. Chapleau is no longer an island. American Behavioral Scientists 53(9), 1344-1366. DOI: 10.1177/0002764210361689.

[11] Convertino, A., ed. (2006): AlpCity Project [Final Report of the INTERREG IIIB Project]. Torino: Regione Piemonte.

[12] Courtney, P., Errington, A. (2003). Small towns as "sub-poles" in European rural development: Policy, theory and methodology. Agricultural Economics Society Annual Conference, University of Plymouth.

[13] Courtney, P., Mayfield, L.., Tranter, R., Jones, P., Errington, A. (2007): Small towns as subpoles in English rural development: investigating urban-rural linkages using sub-regional social accounting matrice. Geoforum 38(6), 1219-1232. DOI: 10.1016/j.geoforum.2007.03.006.

[14] Cudny, W. (2012). Socio-economic transformation of small towns in East Germany after 1990. Colditz case study. Bulletin of Geography. Socio-economic Series 17(1), 33-43. DOI: $10.2478 / v 10089-012-0004-6$.

[15] Édouard, J. C. (2012). La place de la petite ville dans la recherche geographique en France: de la simple monographie au territoire témoin. Annales de Geographie 121(683), 25-42. DOI: 10.3917/ag.683.0025. 
[16] Everitt, J. C., Gill, A. M. (1993). The social geography of small towns. In Bourne, L. S., Ley, D. F., eds., The changing social geography of Canadian cities (pp. 252-264). Montreal: McGill-Queen's University Press.

[17] Fertner, Ch., Groth, N. B., Herslund, L. B., Carstensen, T. A. (2015). Small towns resisting urban decay through residential attractiveness. Findings from Denmark. Geografisk Tidsskrift 115(2), 119-132. DOI: 10.1080/00167223.2015.1060863.

[18] Fonseca, M. L. (2008). New waves of immigration to small towns and rural areas in Portugal. Population, Space and Place 14(6), 525-535. DOI: 10.1002/psp.514.

[19] Fuguit, G. V., Brown, D. L., Beale, C. L. (2012). Rural and small town America. New York: Russell Sage Foundation.

[20] Gunko, M. S. (2014). Small towns in the central part of European Russia: Socioeconomic state and the role in organizing territory. Regional Research of Russia 4(4), 231-239. DOI: 10.1134/S2079970514040054.

[21] Halonen, M., Kotilainen, J., Tykkyläinen, M., Vatanen, E. (2015). Industry life cycles of a resource town in Finland - the case of Lieksa. European Countryside 7(1), 16-41. Doi: 10.1515/euco-2015-0002.

[22] Hampl, M., Marada. M. (2015). Sociogeografická regionalizace Česka. Geografie 120(3), 397-421.

[23] Hannemann, Ch. (2002). 'Soziales Kapital' kleiner Städte - Perspektive für schrumpfende Städte in Ostdeutschland? In Hannemann, Ch., Kabisch, S., Weiske, Ch.: Neue Länder neue Sitten? Transformationsprozesse in Städten und Regionen Ostdeutschlands (p. 1128). Berlin: Schelzky \& Jeep.

[24] Hansmann, R., Mieg, H. A. \& Frischknecht, P. (2012). Principal sustainability components: Empirical analysis of synergies between three pillars of sustainability. International Journal of Sustainable Development \& World Ecology 19(5), 451-459. DOI: 10.1080/13504509.2012.696220.

[25] Heffner, K., Marszał, T., eds. (2005). Problemy rozwoju małych miast w wymiarze lokalnym i regionalnym. Warszawa: Komitet przestrzennego zagospodarowania kraju PAN.

[26] Hinderink, J., Titus, M. (2002). Small Towns and Regional Development: Major Findings and Policy Implications from Comparative Research. Urban Studies 39(3), 379-391. DOI: $10.1080 / 00420980220112748$.

[27] Horeczki, R. (2014). A Dél Dunántúli kisvárosok a fejlesztési tervek tükrében. DETEUROPE 6(3), 97-111.

[28] Ježek, J., (2011). Small towns attractiveness for living, working and doing business. Case study the Czech Republic (pp. 4-11). In Ježek, J., Kaňka, L., eds., Competitiveness and sustainable development of the small towns and rural regions in Europe. Plzeň: University of West Bohemia.

[29] Keckstein, V. (1999). Kleinstädte und Marktgemeinden zwischen Urbanität und Zersiedelung. Revue de Géographie Alpine 87(2), 89-103. DOI: 10.3406/rga.1999.2946.

[30] Knox, P. L., Mayer, H. (2009). Kleinstädte und Nachhaltigkeit. Basel, Boston, Berlin: Birkhäuser.

[31] Kobojek, E., Marszał, T. (2014). Local development and the role of small towns in space organization in Contemporary Poland (pp. 37-60). In Marszał, T., ed., Origin Spatial Development of Contemporary Poland in Łódź University Geographical Research. Łódż: Uniwersytet Łódżki.

[32] Krzysztofik, R., Dymitrow, M., eds. (2015). Degraded and restituted towns in Poland. Göteborg: University of Gothenburg.

[33] Kühn, M. (2015). Small towns in peripheral regions in Germany. In Annales Universitatis Pedagogicae Krakoviensis. Studia Geographica 8, 29-38. 
[34] Kusis, J., Abele, J. (2008). Development strategies of small towns as the basis of sustainability. In Majerová, V., ed.: Countryside - our world (pp. 371-379), Praha: Česká zemědělská univerzita.

[35] Kwiatek-Śołtys, A. (2004). Małe miasta województwa małopolskiego w okresie transformacji systemowej. Kraków: Wydawnictwo Naukowe Akademii Pedagogicznej.

[36] Laborie, J.-P. (1997). Les petites villes et la métropolisation. In: Laborie, J.-P., Renard, J. (eds.): Bourgs et petites villes (s. 21-48). Toulouse: Presses universitaires du Mirail.

[37] Lampić, B., Špes, M. (2007). Sustainable development of small towns. Ljubljana: Univerza v Ljubljani.

[38] Lazzeroni, M., Bellini, N., Cortesi, G. \& Loffredo, A. (2014). The territorial approach to cultural economy. New opportunities for the development of small towns. European Planning Studies 21(4), 452-472. DOI: 10.1080/09654313.2012.722920.

[39] Lorentzen, A. \& van Heur, B. (2012). Cultural political economy of small cities. Milton Park: Routledge.

[40] Mainet, H. (2015). The paradoxical place of small towns in sustainable development policies. What is beyond the images of "places where the living is easy"? Annales Universitatis Pedagogicae Krakoviensis. Studia Geographica 8, 5-11.

[41] Niedermayer, M. (2000). Regulationsweisen der Kleinstadtentwicklung. Eine Analyse peripherer Kleinstädte im Grenzraum von Südthüringen und Nord-Unterfranken. In: Niedermayer, M. (ed.): Kleinstadtentwicklung (pp. 47-375). Würzburg: Geographisches Institut der Universität Würzburg.

[42] Perlik, M., Bätzing, W. (1999). L'avenir des villes des Alpes en Europe. Bern: Verlag des Geographischen Institutes der Universität Bern.

[43] Pumain, D. (1999). Quel rôle pour les villes petites et moyennes des régions périphériques Revue de Géographie Alpine, 2, 169-184. DOI: 10.3406/rga.1999.2950.

[44] Rebernik, D. (2005). Small towns in Slovene urban system. In: Murayama, Y., Du, G. (eds.): Cities in global perspective - diversity and transition (pp. 172-180). Tokyo: College of Tourism of the Rikkyo university / International Geographical Union - Urban Commission.

[45] Repaská, G. (2011). Malé mestá Nitrianského kraja - urbanizácia či suburbanizácia? Geografické informácie 15, 52-63.

[46] Rodríguez Gonzáles, R. (1997). La urbanización del espacio rural en Galicia. Barcelona: Oikos-tau.

[47] Rydz, E. (2006). Rola małych miast w rozwoju obszarów wiejskich. Warszawa: Instytut geografii i przestrzennego zagospodarowania PAN.

[48] Servillo, L., Atkinson, R., Smith, I., Russo, A., Sýkora, L., \& Demazière, Ch. (2013). Small and medium sized towns in their functional territorial context (ESPON interim report]. Luxembourg: ESPON coordination unit.

[49] Slavík, V. (2002). Small Towns of the Slovak Republic within the transformation stage. In: Matlovič, R., Žigrai, F.: Wandel der regionalen Strukturen in der Slowakei und im österreichischslowakischen Grenzgebiet (pp. 146-154). Prešov: Prešovská univerzita.

[50] Sokołowski, D. (1999). Funkcje centralne w zbiorze małych miast i większych osiedli wiejskich w Polsce. Przegląd geograficzny 71(3), 295-316.

[51] Spasić, N., Petrić, J. (2006). The role and development perspectives of small towns in Central Serbia. Spatium (13-14), 8-15, DOI: 10.2298/SPAT0614008S.

[52] Steinführer, A., Kabisch, S. (2005). Images einer langfristig schrumpfenden Stadt. Das Beispiel Johanngeorgenstadt (Sachsen). Berichte zur deutschen Landeskunde 79(1), 5-31. 
[53] Sýkora, L. \& Mulíček, O. (2009). The micro-regional nature of functional urban areas (FUAs): Lessons from the analysis of Czech urban and regional system. Urban Research \& Practice 2(3), 287-307. DOI: 10.1080/17535060903319228.

[54] Vaishar, A., Greer-Wootten, B. (2006). Sustainable development in Moravia: an interpretation of the role of the small-town sector in transitional socioeconomic evolution. In: Bochniarz, Z., Cohen, G. B. (eds.): The environment and sustainable development in the new central Europe (p. 217-231). New York/Oxford: Berghahn Books.

[55] Vaishar, A. et al. (2008). Geografie malých měst. Brno: Ústav geoniky AV ČR.

[56] Vaishar, A., Št’astná, M., Vavrouchová, H., Stejskal, B., Hlisnikovský, L., Kniezková, T., Lipovská, Z., Novotná, K., Pákozdiová, M. Z. (2012). Malá města - motory rozvoje jihomoravského venkova. Brno: Mendelova univerzita.

[57] Vaishar, A., Zapletalová, J. (2007). Suburbanization in small towns - case study Modřice near Brno. Analele Universitatii din Craiova - seria geografie. 10, 112-126.

[58] Vaishar, A., Zapletalová, J. (2009). Small towns as centres of rural microregions. European Countryside 1(2), 70-81. DOI: 10.2478/v10091-009-0006-4.

[59] Vaz, T. N., Nijkamp, P. (2013). Small towns of hope and glory In Vaz, T. N., van Leeuwen, E., Nijkamp, P., eds., Towns in rural world (pp. 3-10). Farnham: Ashgate.

[60] Waitt, G. R., Gibson, C. R. (2006). Creative small cities: Rethinking the creative economy in place. Urban Studies 46(5), 1223-1246. DOI: 10.1177/0042098009103862.

[61] Wuthnow, R. (2013). Small town America. Finding community, shaping the future. Princeton: Princeton University Press.

[62] Zamfir, D., Tălăngă, C., Stoica, I. V. (2009). Romanian small towns searching for their identity. Journal of Urban and Regional Analysis 1(1), 41-53.

[63] Zemanová, J. (2012). Vývoj struktury obyvatelstva malých měst v České republice v letech 1869 - 2001 [Diploma thesis]. Plzeň: West Bohemian University.

[64] Zsilincsar, W. (2003). Future Perspectives for Small Urban Centres in Austria. Geografický časopis 55(4), 309-324.

[65] Zuzańska-Żysko, E. (2004). Przemiany gospodarcze małych miast wojewódzstwa śląskiego. In: Jaźdźewska, I. (ed.): Zróznicowanie warunków źycia ludności w mieście (pp. 131-140). Łódź: Wydawnicztwo Uniwersytetu Łódzkiego. 